Chinese Journal of Urban and Environmental Studies

Vol. 6, No. 1 (2018) 1850002 (20 pages)

(C) World Scientific Publishing Company and

Social Sciences Academic Press (China)

DOI: $10.1142 / \mathrm{S} 2345748118500021$

\title{
Assessing Citizens' Demands for Improving the Urban Environment
}

\author{
Seyedeh-Samira SHAFIEE-MASULEH* \\ Department of Geography and Urban Planning \\ University of Tabriz, Tabriz, East Azerbaijan, Iran \\ s.shafiee@tabrizu.ac.ir \\ Seyed Reza SHAFIEE MASOULEH \\ Department of Geography and Urban Planning \\ University of Guilan, Rasht, Guilan, Iran \\ s.reza.shafiee@gmail.com
}

\begin{abstract}
The main purpose of the research is to provide a better basis for programs seeking to promote responsible citizen participation in urban development plans and projects. The research is based on a survey of 400 citizens in Anzali, a city with a population of approximately 116,000 . In the spring of 2014, data collection was carried out in seven streets functioning as geographical clusters. Survey respondents were selected using convenience sampling. This study is an applied and descriptive survey research. However, the researchers are not satisfied with mere expression of the opinions, demands and suggestions of citizens. They go further to interpret the data and explain and justify them. In order to do that, they provide a convincing argument through searching among the literature and theoretical discussions and make conclusions. The research reveals that if users are properly consulted about municipal decisions, plans and activities, they can make specific and meaningful suggestions for improving the quality of the spaces. On the other hand, the status quo must be changed in order to provide opportunities for place management. In this regard, people should be trained to nurture a sense of responsibility towards the place so that they can become managers of the place.
\end{abstract}

Keywords: Citizen participation; place management; urban streets.

\section{Introduction}

\subsection{Problem statement}

In the introduction to the translation of Lynch's book, Mozayyeni writes: "In order to reside and live, a city is a big house, and as a house should have the attributes and benefits to make a comfortable living, a city should also have the qualities and features to provide comfort and convenience, as well as a warm, intimate and pleasant environment like a house that makes life good and easy" (Lynch, 2008a).

It is right to say that a city is the residence of a set of people with different needs, interests and tastes, and even their perception and touch of the urban spaces are more than

*Corresponding author. 
those of experts. Therefore, experts cannot do anything other than to visit citizens and see what their desires and inferences are (Pāsebān-Hazrat et al., 2003). Accordingly, experts should not have an abstract view of urban issues and accept that these people should prepare for having a city with desirable qualities and features, and that their understanding should make them worthy of such a city.

Streets, as part of the urban spaces, are also an important part of the inhabitants' daily lives. People count on them for such daily activities as travel, shopping and engaging with friends and relatives. Much social life and learning occur along the streets. Good streets are democratic streets, which are meaningful to people, encourage access for everyone, and encourage use and participation. Moreover, these streets are loved and well maintained by their users (Francis, 1991).

Assessment of "citizens" demands on urban spaces, including streets, shows the extent to which their needs are met and indicates their preferences in urban spaces. Understanding such assessments can be useful for effectively managing and providing suitable urban spaces (Shan and Yu, 2014). This is important, given that the extrovert life of people living in Bandar-e Anzali, the result of the culture formed over the past 100 years, has led to a permanent presence of people in the urban spaces. ${ }^{1}$ As far as we know, streets in the city of Anzali have their own particular concept of the past, namely social function, rather than access or activity. People of this city have an old habit of social life outside the confines of their homes, and their presence in urban spaces is permanent for social intercourse.

The main purpose of this research is to provide a better basis for programs that seek to promote responsible citizens' participation in urban development plans and projects. This research focuses on two questions:

(i) Why is it necessary to be aware of the citizens' wishes of and their inferences from the urban spaces?

(ii) How can the public mind be made aware of spaces and their elements?

It is hoped that general guidelines for the second research question can be offered by the answer to the first question. Nevertheless, designing and evaluating practical programs for it should be done with other work.

\subsection{Research background}

Correctly, it can be said that every research implies to recognize previous researches, because no research is done in the vacuum. Nevertheless, one can hardly find a study that directly and independently assesses the "citizens" demands as a move to improve the urban environment with an emphasis on streets. Previous researchers only managed to achieve some of the researches that are close to the subject of this study. An overview of these researches is presented below.

In a study, Aminzāde and Rezābeygi-Sāni (2012) analyze urban landscape design in Atābak neighborhood, Tehran, using six components of participatory regeneration based

\footnotetext{
${ }^{1}$ Naqsh-e Jahan-Pars Consulting Engineers. 2013. Bandar-e Anzali Development Plan, Vol. 2. Rasht: General Directorate of Roads and Urban Development Guilan Province (in Persian).
} 
on theoretical foundations, including involvement of users, consciousness raising and informing, trust building, strengthening and empowerment, attention to stakeholders and influential groups as well as attention to social institutions. Research shows that participation in urban landscape design is not successful in any of the components above. From its point of view, the experience of Atābak neighborhood indicates residents' lack of satisfaction with their residence and people's lack of motivation to renovate their living environment. It is necessary to empower residents and build confidence in urban management in order to benefit from social participation and social movement and achieve a participatory city in light of the active and effective presence of the people and the nongovernmental sector. The results of the survey on the job description of urban landscape designs and their samples (Atābak neighborhood plan) indicate the need to pay special attention to damaged fabrics in all areas, including making, designing, managing and implementing the plan, so that by being engaged in different areas, people are empowered to make decisions about their living environment. A supportive, strategic and flexible reconstruction is not feasible unless with the participation of residents, urban actors, urban experts and private sector investors. Therefore, it requires a process in which nonspecialists play an active role in the clear expression of knowledge, values, preferences and provision of solutions.

A study regarding the city of Estahbān, Fars Province, by Bazi and AbdollāhipurHaqiqi (2013) is based on the assumption that urban-service distributions in Estahbān is not at the discretion of the people. Findings of the research show that in urban-service distributions (the creation and development of service) people have had little participation, neither have municipalities and other urban-service-related organizations conducted any surveys targeted at local people on lack of urban service in Estahbān. Thus, urban service there has hardly met the needs of the urban population. According to Bazi and Abdollāhipur-Haqiqi (2013), questionnaire shows that citizens of Estahbān, are largely willing to cooperate with the municipality and they can determine priorities and needs in urban service as well as ways to address them.

A comprehensive and interesting study conducted in the United States by Burby and Weiss seeks to answer the question of why people relocate to new cities and whether they have gained complete satisfaction with such choices (Bahreyni, 2007). This study suggests that residents' assessment provides concrete ways to improve and design settlements in housing, facilities, service, infrastructure, environmental qualities, growth control, maintenance and safety aspects as well as overall planning (Bahreyni, 2007).

Trancik provides a method in which users' ideas are absorbed at different stages of the design of a neighborhood (Bahreyni, 2007). At first, potential buyers and leaseholders (if known) are interviewed. Afterwards, design criteria are adjusted with the help of interviewees. After completing each neighborhood from the neighborhood plan, new residents are interviewed. Interview answers are used to design and implement neighborhood development plans. In fact, Trancik provides a step-by-step strategy that allows the neighborhood design plan to be evaluated according to the criteria, and the criteria to be modified according to users' views. In this way problems are identified and necessary adjustments are made in the design (Bahreyni, 2007). 
Shan and Yu (2014) study the credibility of citizen assessment of urban green spaces in Guangzhou, China. Their findings validate user assessment as a policy tool of urban green spaces and provide empirical evidence for the credibility of citizen assessment. It encourages city managers to take stock of citizen assessment and even to institutionalize it as standard management of urban public services, including urban green spaces in China and other countries.

Fitzgerald and Durant (1980) argue in a study on citizen assessment and urban management in the age of protest that citizen assessment of urban services could play an important role in the management of contemporary urban affairs. Major implications of this research for public administrators responsible for the delivery of essential urban service are: (1) Continuous pressure for direct citizen participation in the implementation process is highly possible, as citizens pursue a mechanism to address the complaints of the past; (2) when struggling with dissatisfaction with urban services, strategies for compensatory treatment unconsciously targeting certain socioeconomic groups may be ineffective and in vain; (3) it is true that urban agencies play an appropriate role, but citizens still believe otherwise. Voicing their opinions through the appropriate channels of communication with people is likely to be the only available option to reduce negative perceptions.

Desouza and Bhagwatwar (2012) made an interesting study on citizen apps ${ }^{2}$ to solve complex urban problems. They state that urban planners and designers, public managers and elected officials must (a) harness the power of open data being made available to the public to design, develop and revitalize smart urban spaces; (b) encourage emergent solutions of local problems by the public; and (c) pay close attention to citizen-centric forums to tap into vital information that affects the nature and outcome of urban governance. They examined 20 citizen applications that aim to solve urban problems associated with transportation, public utilities and services and public safety. They looked at the range of applications, the types of information used and the effects of these applications not only on the day-to-day lives of people but also on urban governance. They concluded that while citizen apps create opportunities for people to discuss and convey their opinions to the government, there is no way to make sure that their opinions are heard and considered in decision-making. Furthermore, while identifying and creating awareness about local urban issues might be the primary goal of open data initiatives, it is not enough. In the future, citizen apps promised to be seen as a platform for two-way interaction between government and people. Government agencies, through their open data projects, should find a way to make sure that people are kept informed about their progress on solving problems reported by citizens. In addition, future studies could focus on analyzing the social and economic effects of various types of citizen apps. This could help government agencies and urban administrators set their priorities for open data initiatives based on the type of citizen app they want to see developed.

\footnotetext{
${ }^{2}$ The US federal government launched the data.gov initiative in May 2009, making data collected by different government agencies (e.g. National Institutes of Health) accessible to the public. The goal is to make citizens aware of current government projects. Similarly, the citizen.apps.gov platform that was recently launched, allows federal employees to communicate with citizens through blogs, forums and wikis (Desouza and Bhagwatwar, 2012).
} 


\subsection{Research method}

The research was based on a survey of 400 citizens $^{3}$ in Bandar-e Anzali, a city with a population of approximately 116,000. A total of 351 questionnaires (a response rate of $87.8 \%$ ) were used in the final analysis. In spring 2014, data collection was carried out on seven streets functioning as geographical clusters (Fig. 1). Respondents were selected using convenience sampling. In other words, the samples were selected from those who were present in the places at the time of the survey and were willing to participate and familiar with the places. Therefore, participation in the research was voluntary, and citizens were assured of complete confidentiality until the completion of the research. Although the samples were not random in the clusters, Blaikie (2011) states that having limited and nongeneralized information due to the type of sampling is better than having no cognition of the subject. The open-ended questionnaire provides an opportunity for the respondents to express their points of view as they wish. These questions are:

(i) In your opinion, what is/are the distinguishing feature(s) of the place?

(ii) What is unpleasant or bad to you in the place?

(iii) What kinds of changes or reforms (to improve the quality of the spaces) would you prefer if you were allowed to choose?

This experience provides a clear scenario of reforms that can be based on the views and demands of people in an urban space in general and on an urban street in particular, and it shows factor(s) mostly valued by people.

This study is of an applied and descriptive survey research type. However, since the main purpose of the present research is to assess citizens' demands for urban improvement, the researchers, unsatisfied with mere expression of opinions, demands and suggestions of citizens, provide a convincing argument through searching among the literature and theoretical discussions to interpret and justify the data and then make conclusions.

\subsection{Scope of research}

The study focuses on the most densely populated areas of the city in the old fabric of Anzali (the western part of Bandar-e Anzali) or area 6, with a population density of 92.8 people per hectare. Small parts of area 5 and area 7 are also within the scope of research (Fig. 1). The sixth area, covering 150.65 ha, is the smallest urban area. ${ }^{4}$ In this area, Sepah Street, Golestān Street and 30 Meter Street are most crowded. In addition, Imam Khomeini square, fish market (Shanbe Bazaar) and the coastal boulevard of the city (linear park facing the city pier) are among the most important urban spaces. Canals in the city have

\footnotetext{
${ }^{3}$ The sample size was estimated using Cochran's formula, taking into account the $5 \%$ sampling error and the $95 \%$ confidence level, and the highest possible variance ( $p=0.5$ and $q=0.5$ ). Thus, the sample size was calculated as 383 people. For more reliability, the sample size was raised to 400 people.

${ }^{4}$ Naqsh-e Jahan-Pars Consulting Engineers. 2013. Bandar-e Anzali Development Plan, Vol. 1. Rasht: General Directorate of Roads and Urban Development Guilan Province (in Persian).
} 


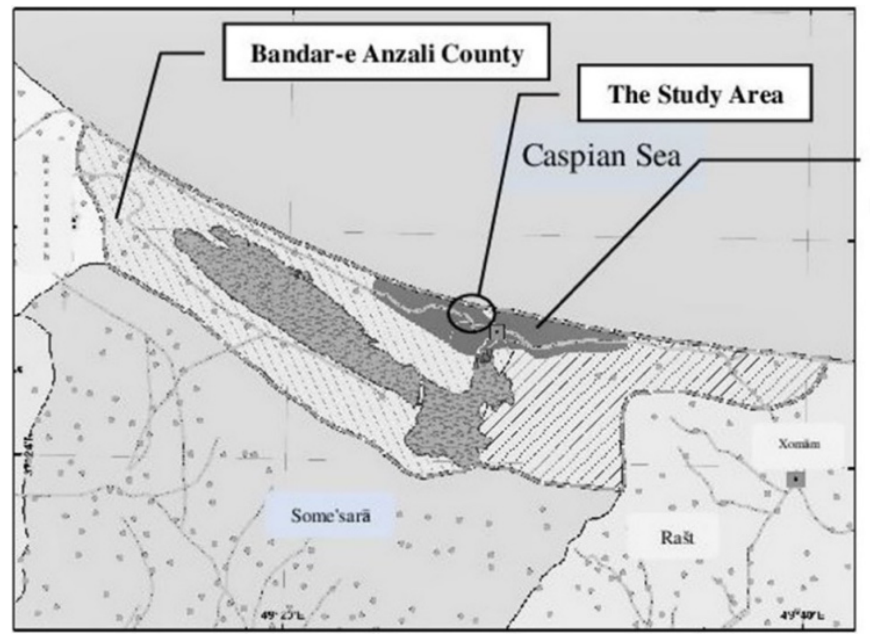

The City of Bandar-e Anzali

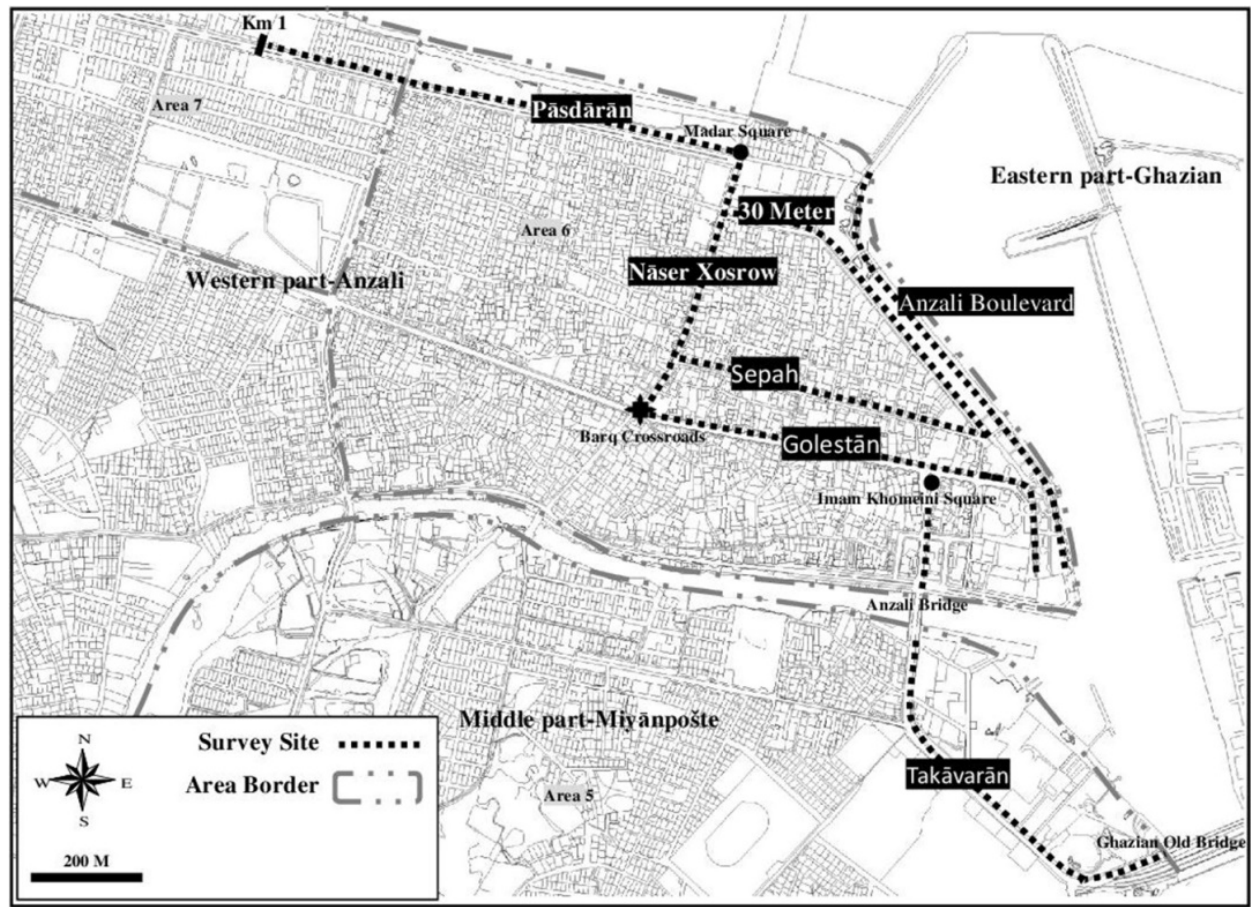

Source: Edited by the authors based on the digital layers of the municipality of Bandar-e Anzali.

Fig. 1. Survey sites and area borders of Bandar-e Anzali.

great potential for playing the role of urban open spaces that have not been exploited thus far.

Like other Iranian cities, the land of Bandar-e Anzali is owned by the municipal government. It makes decisions on urban spaces within the framework of national and local laws. Experts and specialists can help make decisions on urban spaces with their expertise, 
but the municipal government remains the decisive power in almost all aspects. According to the administrative and executive structure, public participation is demonstrated slightly or only as formality (for example, informing), which can create dissonance between the main demands of the citizens and the decisions, plans and activities of the municipal government regarding urban spaces.

\section{Concepts, Views and Theoretical Foundations}

\subsection{The concept of the street as an urban space}

According to Jean Jacobs (Oktay, 2002), streets and their sidewalks are the main public places and most basic organs of a city. In her view, a city is conceived with its streets. If the streets of a city appear interesting, the city appears interesting; if the streets look boring, the city looks boring (Oktay, 2002).

The perceived quality of a city is heavily dependent on the quality of its streets. The interesting and specific features of the streets depend on the size of the blocks, their crosssections [the width of the floor of the streets and their sidewalks, the features of setbacks and the height of adjacent buildings, the multiplicity of entrances to buildings, the presence or absence of showcases (shops), etc.]. Furthermore, the perceived quality of a city is influenced by the speed of vehicular traffic passing along the streets, ways to park cars, uses of ground floor of buildings that are located near the streets and street pavement and furniture (Lang, 2005).

Regarding the types of city paths, planning and designing urban streets requires the most sensitivity and elegance because streets are places where social interactions and urban dynamics reach their own maximum quantity and quality. The minds of the citizens are accumulated from collective memories and shared attitudes about the type and way of civil life. Urban streets are full of events, and citizens come for a variety of reasons and at different times. Visiting important activity centers, window shopping, grocery shopping, or just simply lingering on the streets, seeing others and being seen by them, all of these have transformed urban streets into spaces full of collective and individual events for citizens. The interconnected network of urban streets, which is the result of many years of citizens' efforts to continue urban life, is full of memories, concerns, needs and aspirations of citizens and suggests a kind of life, attitudes, economic level, social relations and other subjective and objective similarities of citizens on a city scale. The most striking feature of urban streets is that they are the product of gradual growth and process of change in a city. They reflect the social, economic and cultural structures of the community rather than the city's physical structure. For this reason, one cannot transform and decorate existing urban streets with an intuitive artistic vision, and blot out collective memories of the face of the street with self-centered decisions, nor can one reduce urban streets to "traffic artery" for the sake of solving vehicular traffic congestion (Xādemi et al., 2010).

\subsection{The need for a direct assessment of citizens' demands}

In most cases of urban design decision-making, a major concern is place-making. However, understanding "insiders" preconception of the experiential quality of a place is very 
difficult (Metin, 2006). A famous example is Marcus's (Riley, 1992) opinion. According to Marcus (Riley, 1992), designers often repeat the ideal and desired scenes from their past in their designs for others (Riley, 1992). The meaning of a space differs from one group to another and, consequently, relationship with it is different. A street, a hangout or a particular square may have a certain symbolic meaning for a group of people or even citizens of a city or a country. Therefore, understanding the meaning and extent of people's relationship with spaces in the urban design process is very important. People's participation in the design process of a city can reveal meanings in the spaces, and the conscious design of the environment mostly reveals these meanings and thus strengthens a relationship with the spaces. Maintaining a relationship with the space brings the personal, group and social identity (Abbāszādegān, 2005).

According to Pākzād (2002), experts and managers have been infected with a disease of "quantitative domination." A major concern is solving quantitative problems, and qualitative consequences of decisions are less considered. They oppose non-identity, lack of unity, insecurity and turmoil, and advocate sustainability, legibility, diversity, changeability and tens of other qualities; nevertheless, they do not know exactly how these qualitative objectives can be achieved. Because these concepts are not touchable and calculable, they are proscribed from the job description of the plans and then the "rational," "scientific" and calculable concepts are discussed. Few people will be allowed to participate in this process. Consequently, in plans, perception and behavior of citizens and the identification of spatial expectations and places in a city are not paid any attention. However, citizens' intellectual and practical participation in plan preparation makes it more realistic and helps the realization of the plan (Pākzād, 2000). Hence, personnel training for place managers and changing the current situation in order to provide opportunities for place managing are rewarding social tasks. In fact, promoting a sense of responsibility towards the place is an effective means of general training, both rationally and morally (Lynch, 2008b).

From the viewpoint of Pākzād (2001), three groups affecting the quality and quantity of urban spaces are managers, ordinary people and experts. In his opinion, each of these three groups has a different approach to a city and its spaces. The first group, managers, is people who are assigned to positions due to their commitment or management experience in another part. They rarely have a good command of urban planning and design issues and therefore assign the complicated decision-making affairs to experts. Since managers consider their main task as the management and coordination in realizing plans and programs, their way of dealing with issues is holistic and executive; that is, they are not interested in the process and complex details of decision-making. In fact, only the final product is important to them. A product concerning the financial, legal, personnel and technical limitations of executors is desirable for managers. The best plan or decision, if not executed, is useless for them. Besides, they themselves frequently offer solutions for fear of inefficiency of suggestions from experts, regardless of the complexity of the issue. They consider themselves servants of people in theory, but they are authoritarians in practice, and they unconsciously consider themselves dominating the fate of city and citizens and giving facilities and services to the people. Although they look for quality, they still give priority to solving the quantitative issues. 
The second group is ordinary people who cover a wide range of strata, including residents, businessmen, individuals and groups that are continually or periodically referring to the space, in this case ordinary Iranians and foreign tourists. People have many different facets, including ethnicity, age, gender, social status and so on, which affect their feelings about the places and the consequences of behaviors. These people mainly see issues in a cross-sectional and tangible way, and they pay attention to what affects their daily lives. Of course, this does not mean to negate the past and future of a city and its spaces; quite the contrary, they have their own memories and spatial expectations of every corner in the space with surprising details. Due to their familiarity with the space, they identify closely many problems and respond accordingly. Interestingly, people understand and express qualities better than quantities. For them, the area or the length and width of the space is not easily understandable, but its coziness or vitality is felt immediately. People always replace the geometric order of the space with the order of life, and they behave and participate in the space according to this order of life. They are creatively engaging with and shaping their surroundings. People may not be able to understand and even scientifically and reasonably explain their needs to the inquirers and researchers; in contrast, when they are in a position of need, their behavior clearly indicates the necessity and priority of their needs (Pākzād, 2001). Accordingly, the most important tool for successful urban management is to use people's participation (Yaqfuri and Rafi'iyān, 2015). People's participation provides more and equal access to resources (Azimi et al., 2015). In addition, a comprehensive plan is a plan that has been implemented with people, not for people (Yaqfuri and Rafi'iyān, 2015).

The third group is composed of experts in various fields of urban affairs. "Experts" perception of "people" is a formless and uneducated mass who are in strong need for civilization training. The real knowledge and tools are in experts' hands and they themselves should be the final decision maker. Participation is just a kind of slogan that can be seen in the financial participation section as much as possible. The experts want the best for their people: the best programs, the best patterns, the best models and plans, and try to use the best of human achievements that the rest of the world has made. In the end, they become upset with failure in implementation of their plans and, for those implemented, with people's discontent with them. Experts' tech-belief is so strong that they think any problem can be solved with formulas and models. In their designs, they deny the ordinary people's feelings and emotions. In their calculations, there are no allowances for women, children, the elderly and the mentally and physically disabled. They call the place which a person uses for his/her activities as "space," and think that it has only form and function. They ignore the meaning of it in the minds of citizens, or they simply do not care about it. They unconsciously consider traffic and transportation as the most important problem of their cities and urban spaces are specific to the crossing. For this reason, they give priority to personal motorists and are concerned with traffic calming. Generally, they forget pedestrians who are several times of motorists in number, or even consider pedestrians as a disruptive factor. They fail to prioritize public transportation. Instead, they are preoccupied with facilitating the movement of private cars. Then they wonder why people are all dissatisfied: both pedestrians and motorists, drivers and passengers and pedestrians and residents (Pākzād, 2001). Therefore, it is obvious that improving the shape of a city in 
a manner that satisfies the real aspirations and needs of people requires a direct assessment of people's demands before, during and after the implementation of urban plans (Bahreyni, 2007).

Rapoport (Tālebi, 2004) calls the city planners and designers for further analysis and talks about the need for their awareness of people's images of environmental quality. From his point of view, "images" are the intersection of man and the environment and the source of behaviors and activities, therefore the designing of environment should be begun with ideas of the image of the quality of the environment desired by people. People usually evaluate, choose or escape from a place based on push-and-pull factors and often choose a place that suits their needs and desires. When one cannot find his/her own desired environment, a range of compromises, escaping incompatibilities or neglects can be created that reduce the quality of the positive relationship between man and the environment (Tālebi, 2004).

From the viewpoint of Xorāsānizāde (Pāsebān-Hazrat et al., 2003), a decline in the quality of urban spaces is due to the interruption of the logical relationship between citizens, experts and managers so that there is inattention to and distrust of urban spaces, and, even worse, less citizens offer suggestions for the reform of these spaces. In his opinion, this is a dangerous phenomenon indicating a lethargy of civilization, and perhaps that many cities have been destroyed as a result. Xorāsānizāde (Pāsebān-Hazrat et al., 2003) believes that we have to address this problem, and that the minds of citizens should be made aware of the spaces and their elements, and in this regard, designers, planners and managers should also understand the significance of their duties and pay more attention to the qualitative aspects of the spaces. What needs to be done is to increase the presence of citizens in urban development plans and projects and win their trust; people need to seriously raise their demands and needs so that experts and managers respond to them.

In sum, it can be said that trust, the largest social capital in cities as a result of interacting and communicating between different groups, should be created. Trust-building leads to the emergence of citizens who feel responsible for urban issues and volunteer participation in planning (Rahnamā'i and Ašrafi, 2007). Therefore, it is possible to increase the sense of responsibility towards the urban places in citizens through building up trust in them. Trust is formed as a result of collective participation in the process of solving urban problems (jointly by citizens, experts and managers). The result is the fulfillment of desires, the sense of satisfaction with and attachment to urban places.

\section{Results and Discussion}

\subsection{Characteristics of survey respondents}

Female respondents were slightly more than male respondents. Female, male and married respondents were, respectively, 55.25\%, 44.75\% and 52\%. Average age was 34.08. In terms of educational level, $52.5 \%$ of respondents had university degrees or other forms of higher education. Respondents with secondary education and lower education level accounted for $42.7 \%$ and $4.8 \%$, respectively. Therefore, most respondents in the sample experienced higher education. The average household income was approximately IRR 20 million (approximately USD 609). 


\subsection{Question 1: Why is it necessary to be aware of the citizens' wishes of and their inferences from the urban spaces?}

People's participation in the development process is highly valued so that development is considered as equivalent to participation or participation as a development goal. Considering that most operating costs of plans are paid directly or indirectly by people, the issue of people's participation before, during and after the implementation of urban plans becomes more tangible. People's participation is one of the basic components of good planning. Without the active participation of people in city affairs, municipalities will not be able to advance their goals. Accordingly, different ways should be provided for people's participation in local affairs (Yaqfuri and Rafi'iyān, 2015).

More importantly, ordinary people are one of the three groups that affect the quality and quantity of urban spaces. If people's needs and demands are met in a space, they will be attracted by it and feel calm and joyful. Otherwise they cannot have their own values in the space. They move away from the space and feel no attachment to it (Pāsebān-Hazrat et al., 2003).

Therefore, it is inevitable to refer to citizens demands of urban spaces in general and urban streets in particular so that today's urban spaces can meet their needs. In other words, it should be accepted that a city is the residence of a set of people with different needs, interests and tastes, and their perception and touch of urban spaces are better or more than those of experts.

In this regard, questions, as stated in Sec. 1, were raised to measure people's demands. Subsequently, the research revealed that due to their familiarity with the space, people can identify closely many problems (unpleasant factors) and understand and express their qualities (distinctive features). In addition, if users are properly consulted about municipal decisions, plans and activities, they can make specific and meaningful suggestions for improving the quality of the spaces. Data, literature and theoretical discussions of the research set the seal on our statements.

\subsubsection{The distinguishing feature(s) of the places from citizens' point of view}

From the viewpoint of Rafi'iyān and Xodā'i (2009), distinction, in other words, the distinguishing feature(s) of a place, is one of the indicators and criteria that affects citizens' satisfaction with the urban spaces. Sajjadzāde (2013) in his experimental study finds that there is a close relationship between the distinctions of places and people's emotional attachments. In his opinion, emotional attachment means the ability to turn a place into an environment that is appropriate to the mental conditions of individuals.

According to the results of the survey (Table 1), respondents in Pāsdārān Street mentioned two features: accessible open spaces/park $(89.47 \%)$ and a relationship with the natural environment/water margin $(85.96 \%)$ in descending order of preference. Moreover, many accesses to the place $(92.98 \%)$ and accessible open spaces/park (80.70\%) in Nāser Xosrow Street, shopping complexes/shopping centers (98.24\%) in Sepah Street, proximity to the Coast Boulevard Park/Anzali Boulevard (94.73\%) and greenery/trees (71.92\%) in 30 Meter Street, greenery/trees $(98.24 \%)$, a relationship with the natural environment/water 
Table 1. The distinguishing features of the places from citizens' point of view (in \%).

\begin{tabular}{|c|c|c|c|c|c|c|c|}
\hline \multirow[b]{2}{*}{ Features } & \multicolumn{7}{|c|}{ Places $(n=351)$} \\
\hline & $\begin{array}{l}\text { Pāsdārān } \\
\text { St. }\end{array}$ & $\begin{array}{c}\text { Nāser } \\
\text { Xosrow St. }\end{array}$ & $\begin{array}{l}\text { Sepah } \\
\text { St. }\end{array}$ & $\begin{array}{l}30 \text { Meter } \\
\text { St. }\end{array}$ & $\begin{array}{l}\text { Anzali } \\
\text { Blvd. }\end{array}$ & $\begin{array}{l}\text { Golestān } \\
\text { St. }\end{array}$ & $\begin{array}{l}\text { Takāvarān } \\
\text { St. }\end{array}$ \\
\hline $\begin{array}{l}\text { A relationship with the natural envi- } \\
\text { ronment/water margin }\end{array}$ & 85.96 & - & - & - & 84.21 & - & - \\
\hline Greenery/trees & - & - & - & 71.92 & 98.24 & - & - \\
\hline Seating space & - & - & - & - & 71.92 & - & - \\
\hline Pier and harbor & - & - & - & - & 52.63 & - & - \\
\hline Motor boating stations & - & - & - & - & 10.52 & - & - \\
\hline Elements and statues & - & - & - & - & 17.54 & - & - \\
\hline Shopping complexes/shopping centers & - & 35.08 & 98.24 & - & - & 71.87 & - \\
\hline $\begin{array}{l}\text { The existence of institutions and } \\
\text { organizations }\end{array}$ & - & - & - & - & - & 26.31 & 17.24 \\
\hline Banking centers & - & - & - & - & - & 85.96 & 68.96 \\
\hline Proximity to the Coast Boulevard Park & - & - & - & 94.73 & - & - & - \\
\hline Accessible open spaces/park & 89.47 & 80.70 & - & - & - & - & 34.48 \\
\hline Many accesses to the place & - & 92.98 & - & - & - & - & - \\
\hline Public welfare space/public library & 21.05 & 26.31 & - & - & - & - & - \\
\hline The presence of tourists in the street & 17.54 & - & - & - & - & - & - \\
\hline Accommodation facilities & 12.28 & - & - & - & - & - & - \\
\hline Buildings with architectural value & - & - & 7.01 & - & - & - & 15.51 \\
\hline Bridge & - & - & - & - & - & - & 56.89 \\
\hline Communication centers & - & - & - & - & - & - & 18.96 \\
\hline Market & - & - & - & - & - & - & 87.93 \\
\hline
\end{tabular}

Source: The authors' research findings.

margin $(84.21 \%)$, seating space $(71.92 \%)$ and pier and harbor $(52.63 \%)$ in Anzali Boulevard, banking centers $(85.96 \%)$ and shopping complexes/shopping centers $(71.87 \%)$ in Golestān Street and finally, market (87.93\%), banking centers (68.66\%) and bridge/ Ghazian Old Bridge (56.89\%) in Takāvarān Street accounted for the highest percentages of responses.

\subsubsection{Unpleasant factors in the places from the citizens' point of view}

The loss of sense of belonging is somehow caused by the loss of quality of urban spaces, which itself causes much harm to citizens. Therefore, it is better to know the causes in this regard and examine them according to expert advice (Pāsebān-Hazrat et al., 2003), since people want authenticity, security and sense of belonging. They want to live in environments that are not only comfortable and humane, but also have beautiful elements that lead their soul towards innovation and progress (Tibalds, 2004).

According to the results of the survey (Table 2), unpleasant factors accounting for the largest percentage of responses are as follows: the absence of paving in parts of the sidewalks $(98.24 \%)$, the transfer of sewage to the sea $(98.24 \%)$, garbage $(91.22 \%)$, inadequate asphalt $(71.92 \%)$ and lack of adequate greenery/trees $(63.15 \%)$ in Pāsdārān 
Street, lack of adequate greenery/trees (78.94\%) in Nāser Xosrow Street, lack of greenery/trees $(96.49 \%)$, vehicle traffic $(89.47 \%)$, vehicles parked along the side of the street (next to the curb) $(75.43 \%)$ and the narrow width of the sidewalk and the street (70.18\%) in Sepah Street, the lack of access to the public transportation system (85.96\%) and the quiet street with little or no traffic $(66.66 \%)$ in 30 Meter Street, hookah bars $(54.38 \%)$ and the unpleasant conditions of sanitary facilities $(52.63 \%)$ in Anzali

Table 2. Unpleasant factors in the places from citizens' point of view (in \%).

\begin{tabular}{|c|c|c|c|c|c|c|c|}
\hline \multirow[b]{2}{*}{ Factors } & \multicolumn{7}{|c|}{ Places $(n=351)$} \\
\hline & $\begin{array}{l}\text { Pāsdārān } \\
\text { St. }\end{array}$ & $\begin{array}{c}\text { Nāser } \\
\text { Xosrow St. }\end{array}$ & $\begin{array}{l}\text { Sepah } \\
\text { St. }\end{array}$ & $\begin{array}{l}30 \text { Meter } \\
\text { St. }\end{array}$ & $\begin{array}{l}\text { Anzali } \\
\text { Blvd. }\end{array}$ & $\begin{array}{l}\text { Golestān } \\
\text { St. }\end{array}$ & $\begin{array}{l}\text { Takāvarān } \\
\text { St. }\end{array}$ \\
\hline Hookah bars & - & - & - & - & 54.38 & - & - \\
\hline Garbage & 91.22 & - & - & - & 10.52 & 12.28 & - \\
\hline Lack of social security & 8.77 & 3.44 & - & 8.77 & 5.26 & 7.01 & 3.44 \\
\hline Inappropriate seating arrangement & - & - & - & - & 14.03 & - & - \\
\hline $\begin{array}{l}\text { The unpleasant conditions of sanitary } \\
\text { facilities }\end{array}$ & - & - & - & - & 52.63 & - & - \\
\hline The lack of access to parking & - & 17.54 & - & - & - & 63.15 & 84.48 \\
\hline Vehicular traffic congestion & - & 26.31 & - & - & - & 77.19 & 84.21 \\
\hline Abandoned worthwhile old buildings & - & - & - & - & - & 10.52 & - \\
\hline $\begin{array}{l}\text { Vehicles parked along the side of the } \\
\text { street (next to the curb) }\end{array}$ & - & - & 75.43 & - & - & 56.14 & - \\
\hline Traffic plan, upon arrival of tourists & - & - & - & - & - & 17.54 & - \\
\hline $\begin{array}{l}\text { The lack of access to the public } \\
\text { transportation system }\end{array}$ & - & - & - & 85.96 & - & - & - \\
\hline The quiet street with little or no traffic & - & - & - & 66.66 & - & - & - \\
\hline An inactive facade/no retail shops & - & - & - & 43.85 & - & - & - \\
\hline $\begin{array}{l}\text { The dark and dirty roofs of the cafes } \\
\text { on the edge of the Coast Boulevard } \\
\text { Park along with an unpleasant } \\
\text { smell }\end{array}$ & - & - & - & 17.54 & - & - & - \\
\hline Lack of adequate greenery/trees & 63.15 & 78.94 & - & - & - & - & 67.24 \\
\hline Lack of greenery/trees & - & - & 96.49 & - & - & - & - \\
\hline $\begin{array}{l}\text { Lack of spaces for pause and } \\
\text { relaxation outside the park }\end{array}$ & 19.29 & 17.54 & - & - & - & - & - \\
\hline $\begin{array}{l}\text { Lack of spaces for pause and } \\
\text { relaxation }\end{array}$ & - & - & 43.85 & - & - & - & - \\
\hline $\begin{array}{l}\text { The lack of the quality of paving in } \\
\text { parts of sidewalks }\end{array}$ & - & 35.08 & - & - & - & - & 37.93 \\
\hline $\begin{array}{l}\text { The absence of paving in parts of } \\
\text { sidewalks }\end{array}$ & 98.24 & - & - & - & - & - & - \\
\hline Occupying sidewalks by shopkeepers & - & 21.05 & - & - & - & - & - \\
\hline $\begin{array}{l}\text { Sidewalks occupied by building } \\
\text { materials }\end{array}$ & 36.84 & - & - & - & - & - & - \\
\hline Inadequate asphalt & 71.92 & - & - & - & - & - & 18.96 \\
\hline The transfer of sewage to the sea & 98.24 & - & - & - & - & - & - \\
\hline $\begin{array}{l}\text { The narrow width of the sidewalks and } \\
\text { the street }\end{array}$ & - & - & 70.18 & - & - & - & - \\
\hline
\end{tabular}


Table 2. (Continued)

\begin{tabular}{lcccccccc}
\hline & \multicolumn{7}{c}{ Places $(n=351)$} \\
\cline { 2 - 8 } & Pāsdārān & Nāser & Sepah & 30 Meter & Anzali & Golestān & Takāvarān \\
Factors & St. & Xosrow St. & St. & St. & Blvd. & St. & St. \\
\hline Vehicle traffic & - & - & 89.47 & - & - & - & - \\
The ugly facade of ruined buildings & - & - & - & - & - & - & 17.24 \\
$\begin{array}{l}\text { The lack of order and harmony/the } \\
\text { space disorder }\end{array}$ & - & - & - & - & - & - & 8.62 \\
Anzali's unfinished new bridge & - & - & - & - & - & - & 53.44 \\
\hline
\end{tabular}

Source: The authors' research findings.

Boulevard, vehicular traffic congestion $(77.19 \%)$, the lack of access to parking $(63.15 \%)$ and vehicles parked along the side of the street (next to the curb) (56.14\%) in Golestān Street and finally, the lack of access to parking (84.48\%), vehicular traffic congestion (84.21\%), lack of adequate greenery/trees (67.24\%) and Anzali's unfinished new bridge $(53.44 \%)$ in Takāvarān Street.

\subsubsection{Citizens' suggestions for changing and reforming the places}

This part reveals the importance of people's awareness of solutions to improve the urban spaces in general and the urban streets in particular, and visualize their desired scenario. It is also an ideal state in which users themselves will be the designers and builders of the space that they will occupy. The suggestions made by citizens for changing and reforming the places are listed in Tables 3-9.

According to Table 3, urban space improvement/sidewalk flooring (96.49\%), garbage displacement at regular hours $(91.22 \%)$, the presence of greenery/trees $(89.47 \%)$, sustainable urban sewage system construction (71.92\%) and establishing banking centers $(66.66 \%)$ in Pāsdārān Street accounted for the highest percentages of responses.

According to Table 4 , the presence of greenery/trees $(71.92 \%)$, changes in street lighting $(68.42 \%)$ and creating parking lots to increase access $(50.87 \%)$ accounted for the highest percentages of responses for reform suggestions collected in Nāser Xosrow Street.

According to Table 5, the presence of greenery/trees (91.22\%), a complete removal of vehicle traffic $(80.70 \%)$, creating spaces for pause and relaxation outside the park $(54.38 \%)$ and changes in street lighting $(50.87 \%)$ accounted for the highest percentages of responses for reform suggestions collected in Sepah Street.

According to Table 6, providing access to the place through the public transportation system $(92.98 \%)$ and the removal of the fence between 30 Meter Street and the Coast Boulevard Park/creating garden stairs $(84.21 \%)$ accounted for the highest percentages of responses for reform suggestions collected in 30 Meter Street.

According to Table 7, vegetation/seasonal floriculture $(77.19 \%)$ and creating a pergola passage $(66.66 \%)$ accounted for the highest percentages of responses for reform suggestions collected in Anzali Boulevard. 
Table 3. The suggestions made by Pāsdārān Street users for reforming (improving the quality of the spaces).

\begin{tabular}{lc}
\hline Suggestions & Percent \\
\hline Garbage displacement at regular hours & 91.22 \\
Urban space improvement/sidewalk flooring & 96.49 \\
Sustainable urban sewage system construction & 71.92 \\
Optimal use of the beach and tourist attraction & 17.54 \\
The presence of greenery/trees & 89.47 \\
Creating bicycle paths & 15.78 \\
Changes in street lighting & 22.80 \\
Applying the urban planning and design experts & 14.03 \\
Creating spaces for pause and relaxation outside the park & 22.80 \\
Creating shopping centers & 17.54 \\
Installing the bus shelter & 14.03 \\
Establishing banking centers & 66.66 \\
\hline
\end{tabular}

Source: The authors' research findings.

Table 4. The suggestions made by Nāser Xosrow Street users for reforming (improving the quality of the spaces).

\begin{tabular}{lr}
\hline Suggestions & Percent \\
\hline Urban space improvement/sidewalk flooring & 33.33 \\
Creating parking lots to increase access & 50.87 \\
Creating spaces for pause and relaxation outside the park & 40.35 \\
The presence of greenery/trees & 71.92 \\
Police presence & 3.44 \\
Changes in street lighting & 68.42 \\
\hline
\end{tabular}

Source: The authors' research findings.

Table 5. The suggestions made by Sepah Street users for reforming (improving the quality of the spaces).

\begin{tabular}{lc}
\hline Suggestions & Percent \\
\hline Creating spaces for pause and relaxation & 54.38 \\
The presence of greenery/trees & 91.22 \\
Urban space improvement/sidewalk flooring & 17.54 \\
A complete removal of vehicle traffic & 80.70 \\
Erecting statues and elements & 12.28 \\
Changes in street lighting & 50.87 \\
\hline
\end{tabular}

Source: The authors' research findings.

According to Table 8, creating parking lots to increase access $(89.47 \%)$, urban space improvement/improving the facade of buildings $(56.41 \%)$ and the presence of greenery/ trees $(52.63 \%)$ accounted for the highest percentages of responses for reform suggestions collected in Golestān Street. 
Table 6. The suggestions made by 30 Meter Street users for reforming (improving the quality of the spaces).

\begin{tabular}{lr}
\hline Suggestions & Percent \\
\hline The removal of ruined buildings & 17.54 \\
The removal of the fence between 30 Meter Street and the Coast & 84.21 \\
$\quad$ Boulevard Park/creating garden stairs & 49.12 \\
Creating active facades/retail shops & 19.29 \\
Using the mobile-ATM systems & 92.98 \\
Providing access to the place through the public transportation system & 8.77 \\
Police presence & 28.07 \\
Urban space improvement/sidewalk flooring & 17.54 \\
Urban space improvement/painting the roofs of the cafes on the edge of & \\
$\quad$ the Coast Boulevard Park & \\
\hline
\end{tabular}

Source: The authors' research findings.

Table 7. The suggestions made by Anzali Boulevard users for reforming (improving the quality of the spaces).

\begin{tabular}{lr}
\hline Suggestions & Percent \\
\hline Creating a pergola passage & 66.66 \\
Creating shopping centers with reasonable prices & 17.54 \\
Using the mobile-ATM systems & 40.35 \\
Police presence & 5.26 \\
Garbage displacement at regular hours & 10.52 \\
Creating outdoor play spaces for children & 17.54 \\
Recreational facilities/creating a cycling route & 28.07 \\
Using the space to hold street theaters & 14.03 \\
Urban space improvement/sidewalk flooring & 14.03 \\
Urban space improvement/curb painting in harmony with nature & 26.31 \\
The use of water in the space/the water and light dance & 43.85 \\
Accessibility for the disabled/making appropriate urban space for the disabled & 14.03 \\
Vegetation/seasonal floriculture & 77.19 \\
Creating small sanitary facilities in different parts of the space with optimal service & 17.54 \\
Installing drinking-fountain & 21.05 \\
Installing street clocks in different parts of the space & 14.03 \\
Appropriate seating arrangements for better social interaction & 12.28 \\
\hline
\end{tabular}

Source: The authors' research findings.

Finally, according to Table 9, finishing the bridge $(72.41 \%)$, creating parking lots to increase access $(62.06 \%)$ and the presence of greenery/trees $(58.62 \%)$ accounted for the highest percentages of responses for reform suggestions collected in Takāvarān Street.

These data provide a clear scenario of reforms that can be based on the views and demands of people in urban spaces in general and in an urban street in particular, and it shows factor(s) mostly valued by people. Hence, identifying and recognizing the distinguishing features (values) as well as the unpleasant factors (problems) of the places from 
Table 8 . The suggestions made by Golestān Street users for reforming (improving the quality of the spaces).

\begin{tabular}{lr}
\hline Suggestions & Percent \\
\hline Police presence & 7.01 \\
Garbage displacement at regular hours & 12.28 \\
Urban space improvement/sidewalk flooring & 42.10 \\
Urban space improvement/improving the facade of buildings & 56.14 \\
The presence of greenery/trees & 52.63 \\
Creating parking lots to increase access & 89.47 \\
Creating spaces for pause and relaxation outside the park & 24.56 \\
\hline
\end{tabular}

Source: The authors' research findings.

Table 9. The suggestions made by Takāvarān Street users for reforming (improving the quality of the spaces).

\begin{tabular}{lr}
\hline Suggestions & Percent \\
\hline Police presence & 3.44 \\
Finishing Anzali's new bridge & 72.41 \\
Urban space improvement/sidewalk flooring & 37.93 \\
Creating parking lots to increase access & 62.06 \\
The presence of greenery/trees & 58.62 \\
The removal of ruined buildings & 27.58 \\
Creating spaces for pause and relaxation outside the park & 17.24 \\
Changes in street lighting & 41.37 \\
\hline
\end{tabular}

Source: The authors' research findings.

the citizens' point of view and suggestions made by them for changing and reforming the places will provide the most effective intervention strategy in the urban structure as this study shows that citizens' assessment provides concrete ways to improve and design the streets in terms of facilities, service, infrastructure, environmental qualities, maintenance and safety and overall planning. Therefore, we find out that awareness of the citizens' wishes of and their inferences from the urban spaces is necessary and previous researches (see, for example, Aminzāde and Rezābeygi-Sāni, 2012; Bazi and Abdollāhipur-Haqiqi, 2013; Bahreyni, 2007; Shan and Yu, 2014; Fitzgerald and Durant, 1980) set the seal on it.

\subsection{Question 2: How can the public mind be made aware of spaces and its elements?}

Since this research presumes streets to be one of the main manifestations of the urban space, the concept of urban street is used to answer this question.

It can be said that citizens could participate in urban streets with different tricks and at different levels. Since the issues of these spaces are diverse, one cannot expect that all issues, including monitoring and control, construction and implementation, care and 
maintenance, etc., could be accomplished by a single urban organ. The most efficient mechanism is to use citizens' participation, including shopkeepers, the owners and users of buildings on the street edge, the space's audiences, etc. on the one hand and the organizations involved in urban affairs on the other. Citizens' participation in the preservation of the urban streets leads to social monitoring, which in turn improves the social image of the space and increases its security, and increased security again leads to more citizen involvement, forming a virtuous circle (Xādemi et al., 2010).

It should be further added that direct participation of street users in the process of design and management would help citizens to continuously engage with the streets. Significant advances have been made in developing participatory approaches that allow street users to directly engage with the creation and maintenance of neighborhoods and urban centers. Streets must also be modified by their users to adapt to the diverse and varied needs and activities of the community. Open spaces with fitness and play equipment encourage children to use the street environment. Elements purchased by residents or shopkeepers, for example, movable chairs and pots, can help with local control and monitoring as well as fostering a sense of responsibility towards the street environment. Researches have proven that users who turn vacant lots into local gardens and plant flowers on the sidewalks often encourage other people to participate in the improvement and care of the rest of the street (Francis, 1991).

Considering the data above and what has already been mentioned in Sec. 3.2, logical and effective communication between experts, managers and citizens can be made by activating the cultural and social institutions and creating the appropriate subjective ground through research and extensive advertisements as well as investment, facilitating dialog on issues and problems of a city in general and their urban spaces in particular. Consequentially, rulers of a city can know the needs and demands of their citizens and respond to them in plans. As a result of the interconnection between these groups, trust, as one of the largest social capital in cities, develops. This trust will lead to the emergence of citizens who feel responsible for urban issues and have voluntary participation in planning. This will be very effective in strengthening the public space in a city. Authorities can use the functional quality of the spaces in a city as one of the most powerful tools to create amusement, natural beauty and open spaces for citizens. Thus, they can benefit a city through the creation of a city with a unique identity for its inhabitants, increasing tourist and economic investment and helping to create health and improve the quality of life. Therefore, the current situation should be changed in order to provide opportunities for managing the place. In this regard, people should be trained to nurture a sense of responsibility towards the place so that they can become managers of the place.

\section{Conclusion}

This study shows that it is necessary to be aware of the citizens' wishes of and their inferences from the urban spaces, because due to their familiarity with the space, people could find closely many problems (unpleasant factors), and understand and express the qualities (distinctive features). This reveals people's awareness of solutions to improve the urban spaces in general and the urban streets in particular, and visualizes their own desired 
scenario. However, the results of this study indicate that no consensus has been reached on users' demands of the street as an urban space. This may be due to the diverse needs of place users and the various features of the streets surveyed. However, this study illustrates the fact that every place must be able to meet the following needs: (1) maintaining valuable elements; (2) planning and designing in order to create the elements and factors that are desirable but do not exist at present; and (3) eliminating unpleasant factors with negative impacts on the quality of urban environment. Only in this case, the quality of the environment becomes practical. In examining the qualitative factors of the environment, it is necessary to note that the qualitative factors should be determined both by the professionals and by ordinary people themselves. To consultant engineers, this may be a difficult and costly task and would slow down their work. However, if the quality of the environment and the full implementation of the proposed plans are considered, the only solution will be to pay attention to the demands, needs and opinions of the actual employers, in other words, the community in general and the interest groups in particular. The result is a guarantee of the implementation of the plans and the realization of a sense of satisfaction. In addition, the study shows that through developing participatory approaches and promoting a sense of responsibility towards urban issues by building trust as a result of the interconnection between experts, managers and citizens, the public mind can be made aware of spaces and its elements.

\section{Suggestions}

It has been said that the people of the studied city have an old habit of social life outside the confines of their homes, and their presence in the urban spaces is permanent for social intercourse. On the other hand, the present study shows that users of the spaces could make specific and meaningful suggestions for improving the space's quality. Hence, it is suggested that space users be interviewed to improve and design city spaces. They are asked to find problems (unpleasant factors), and understand and express the qualities (distinctive features) and provide suggestions for space reform. Then, interview answers should be used to design and carry out space development plan, and the criteria should be modified based on users' views and interpretations. Thus, conflict cases are understood and necessary reforms are carried out. That is how people are trained to be designers and builders of the space that they will occupy.

\section{References}

Abbāszādegān, Mostafā. 2005. "The Socio-Psychological Dimensions of the Urban Spaces." International Journal of Engineering Sciences of Iran University of Science and Technology, 16(1): 149-172 (in Persian).

Aminzāde, Behnāz, and Raziye Rezābeygi-Sāni. 2012. "An Evaluation of the Importance of Participation in Urban Landscape Designs in Order to Provide a Suitable Process for the Reconstruction of Damaged Fabrics." Journal of Geography and Environmental Planning, 17(3): 29-40 (in Persian).

Azimi, Nuroddin, Rezā Esmā'ilpur, and Samirā Heydari. 2015. "The Factors Affecting Citizen Electronic Participation in Urban Affairs Management.” Journal of Urban and Regional Studies, 7(26): 189-206 (in Persian). 
Bahreyni, S. Hoseyn. 2007. Urban Design Process. Tehran: University of Tehran Press (in Persian).

Bazi, Xodārahm, and Abolfazl Abdollāhipur-Haqiqi. 2013. "Analysis of the Spatial Distribution of Urban Service Based on People's Demand, Case Study: The City of Estahbān." Journal of Fine Arts, Architecture and Urbanism, 24(1): 201-214 (in Persian).

Blaikie, Norman. 2011. Designing Social Research. Tehran: Ney Press (in Persian).

Desouza, Kevin C., and Akshay Bhagwatwar. 2012. "Citizen Apps to Solve Complex Urban Problems." Journal of Urban Technology, 19(3): 107-136.

Fitzgerald, Michael R., and Robert F. Durant. 1980. "Citizen Evaluations and Urban Management: Service Delivery in an Era of Protest." Public Administration Review, 40(6): 585-594.

Francis, Mark. 1991. "The Making of Democratic Streets." In Public Streets for Public Use, ed. Anne Vernez Moudon, pp. 192-213. New York: Columbia University Press.

Lang, John T. 2005. Urban Design: A Typology of Procedures and Products. Amsterdam: Elsevier.

Lynch, Kevin. 2008a. The Image of the City. Tehran: University of Tehran Press (in Persian).

Lynch, Kevin. 2008b. A Theory of Good City Form. Tehran: University of Tehran Press (in Persian).

Metin, Sinem. 2006. "Public Space in the Millennium Case Study of Millennium Park, Chicago, II." PhD diss. Cincinnati: University of Cincinnati.

Oktay, Derya. 2002. "The Quest for Urban Identity in the Changing Context of the City: Northern Cyprus." Cities, 19(4): 261-271.

Pākzād, Jahānšāh. 2000. "Urban Design in a Development System.” Quarterly Journal of Urban Management, 1(3): 30-41 (in Persian).

Pākzād, Jahānšāh. 2001. "Expert Culture and People's Culture." Quarterly Journal of Urban Management, 1(8): 32-41 (in Persian).

Pākzād, Jahānšāh. 2002. "The Quality of Urban Environment, the Citizens' Belated Demand." Quarterly Journal of Urban Management, 1(9): 6-15 (in Persian).

Pāsebān-Hazrat, Qolāmrezā, Mohsen Xorāsāni-Zade, Jahānšāh Pākzād, and MohammadHoseyn Jahān-S̄āhi. 2003. "An Experts' Discussion in the Panel Discussion of Urbanism Queries about the Quality and Features of the Urban Spaces." Urbanism Queries Journal, 1(6): 26-37 (in Persian).

Rafi'iyān, Mojtabā, and Zahrā Xodā'i. 2009. "The Indices and Criteria Affecting Citizens' Satisfaction with Urban Public Spaces." Rahbord Journal, 18(53): 227-248 (in Persian).

Rahnamā'i, Mohammad-Taqi, and Yusof Ašrafi. 2007. "The Public Spaces of the City and Its Role in the Formation of Civil Society from the Viewpoint of Urban Planning." Geography (Journal of Geographical Society of Iran), 18(14-15): 23-45 (in Persian).

Riley, Robert B. 1992. "Attachment to the Ordinary Landscape." In Place Attachment, eds. Irwin Altman and Setha M. Low, pp. 13-35. Boston: Springer.

Sajjadzāde, Hasan. 2013. "The Role of Place Attachment in the Identity of Urban Squares, Case study: Square Tomb, Hamadān.” Journal of Bagh-e Nazar, 10(25): 79-88 (in Persian).

Shan, Xi-Zhang, and Xijun Yu. 2014. "Citizen Assessment as Policy Tool of Urban Public Services: Empirical Evidence from Assessments of Urban Green Spaces in China." Sustainability, 6(11): 7833-7849.

Tālebi, Žâle. 2004. "Social Relations in the Urban Spaces." Journal of Social Sciences Letters, 11(4): 161-180 (in Persian).

Tibalds, Francis. 2004. Making People-Friendly Towns: Improving the Public Environment in Towns and Cities. Isfahan: Khak (in Persian).

Xādemi, Mas'ud, Mohammad-Rezā, and Rojā Ali-Pur. 2010. "An Introduction to the Concept of Street as the Urban Space: An Attitude to Contemporary Theories and Thoughts." Monthly Journal of Art, (142): 38-45 (in Persian).

Yaqfuri, Hoseyn, and Sajjād Rafi'iyān. ( 2015). "Investigating the Performance of Urban Management in Relation to Citizens' Participation in Urban Affairs (A Case Study of the City of Fasā)." Journal of Urban and Regional Studies, 7(27): 81-100 (in Persian). 